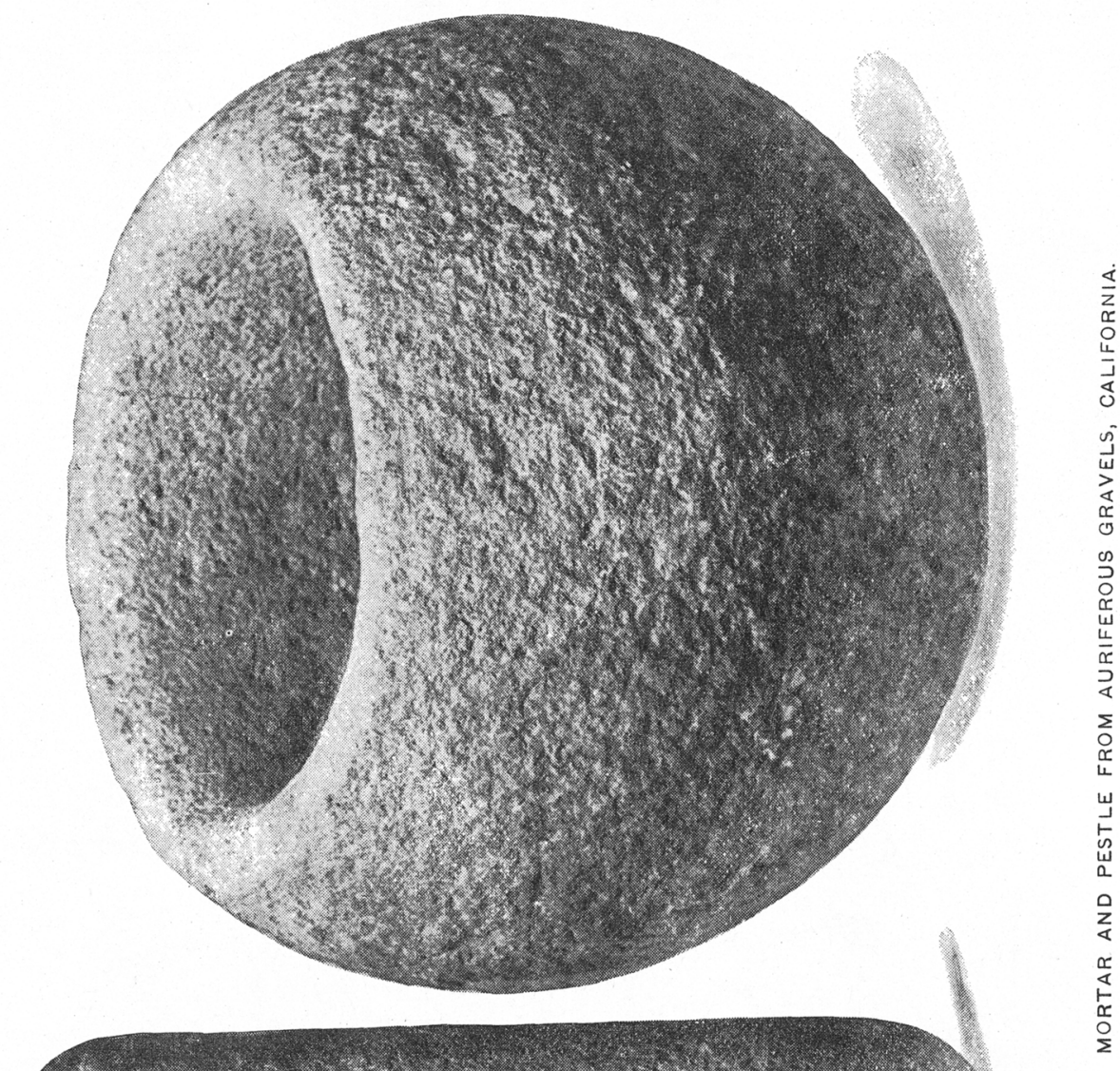

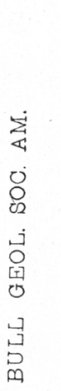




\section{ANTIQUITIES FROM UNDER TUOLUMNE TABLE MOUNTAIN IN CALIFORNIA}

BY GEORGE F. BECKER.

(Read before the Society December 30, 1890.)

CONTENTS.

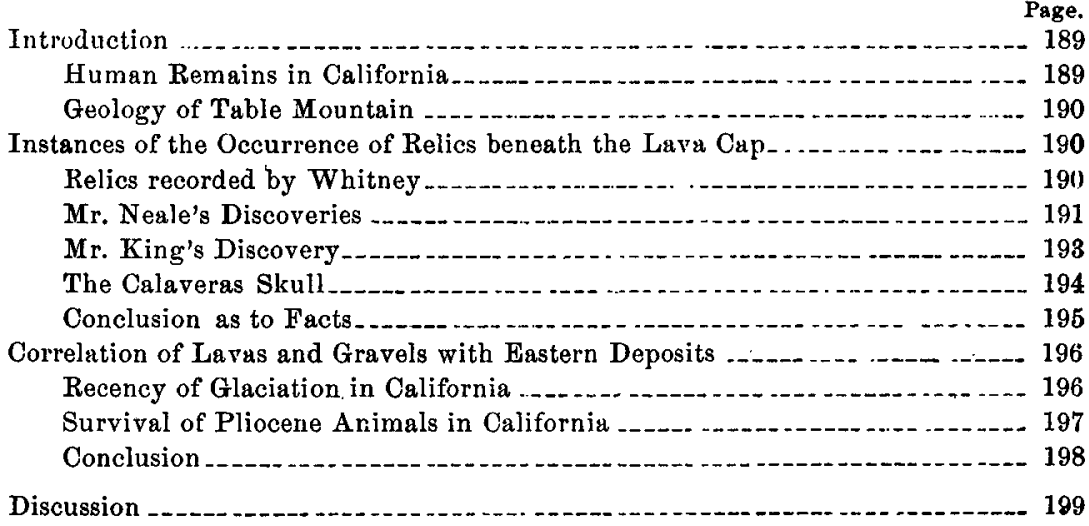

\section{INTRODUCTION.}

Human Remains in California.-It is well known that implements and human bones have been reported from beneath the great lava-flows which cover many of the auriferous gravel deposits of California. From the same gravels the partially fossilized bones of extinct quadrupeds have been obtained, as well as many plants. The plants were regarded as Tertiary by Lesquereux ; and some at least of the mammals, such as Rhinoceros hesperius, are generally recognized as Pliocene, while others, for instance Mastodon americanus, occur in the Quaternary if they are not confined to it. It was held by Whitney that the gravels were Pliocene, and this view has met with very general acceptance. The accumulation of the gravels and the eruption of the flows of lava which forms the cap-rock preceded the glaciation of the Sierra, a fact which lends strong support to the determination of age. 
The assertion that human remains or implements of any kind are found with such fossils is surprising enough to provoke skepticism; but when it must be added that the implements said to have been discovered in these deposits are most unquestionably neolithic, on a level so far as workmanship is concerned with those in use by the California Indians during the present century, and that the famous Calaveras skull is of no lower type than that of the living Indians of the northwest, it cannot be wondered that many European naturalists and some American authorities refuse to accept as genuine the discoveries announced.

If such an association of remains actually occurs, theories must be modified to fit the fact; but novel facts require evidence as strong as their apparent improbability is great.

I have come into possession of proofs of the occurrences in question which are in some respects more convincing than any yet brought forward. I propose to lay these before the Society and then to make a suggestion as to the method of recouciling these facts with those observed elsewhere.

Geology of Table Mountain.-The history of the Tuolumne Table mountain is briefly as follows: Long before glaciation began in the Sierra the Stanislaus river pursued a course nearly parallel to its present bed, but some three miles further southward. It filled a broad channel with coarse gravels which have since become compact and partially indurated. After these gravels had reached a thickness of some 200 feet there was an eruption of basalt which ran down the channel and covered it with an even-topped sheet of lava often 150 feet thick. The glaciation of the Sierra began after this flow, and seemingly soon after it. During the glacial period of California the Stanislaus, displaced from its former bed, cut a new and far deeper one, so that the river now runs a couple of thousand feet below the top of Table mountain. It must clearly have eroded this great depth since the lava flow, and the lava sheet remains as the cap of a relatively elevated mass.

The gravels of Table mountain have yielded and still yield much gold, and very numerous tunnels have been driven into the mass for the purpose of finding the precious metal. In the course of these explorations fossils, including mastodon remains, have certainly been found. It is also asserted that human relics have been discovered beneath the lava cap.

\section{Instances of the Occurrence of Relics beneath the Lava Cap.}

Relics recorded by Whitney.-The following is a brief resumé of the discoveries of human relics reported by Professor J. D. Whitney :* Dr. Perez Snell of Sonora picked from a car-load of gravel, as it was coming out from under Table mountain, a stone grinding implement which was examined by Professor Whitney. Dr. Snell also possessed many other implements and a 
human jaw which had been given him by miners, among whom his practice lay, as coming from these gravels. Mr. Paul K. Hubbs, once state superintendent of public instruction in California, was present in July, 1857, when a small piece of a human skull was taken from a sluice in which pay gravel was being washed at the Valentine shaft, near Shaw's flat. The gravel still adhered to this fragment when Mr. Hubbs received it, and the shaft through which the material was brought to the surface was a boarded one, so that the bone (it is believed) could not have dropped into the shaft from near the surface, where also there was no gravel. Mr. Albert Walton, one of the owners of this claim, also states that a mortar was found in the gravel. Mr. Oliver W. Stevens, about 1853, picked from a car-load of dirt at the Sonora tunnel a mastodon tooth containing pyrite and a large perforated marble bead, which came into Professor Whitney's possession and shows that pyrite had flled or encrusted the hole. Stevens made an affidavit as to this discovery. Mr. Llewellyn Pierce made a sworn statement that about 1862 he dug up a mortar in a tunnel on the Boston Tunnel Company's claim, 1800 feet from the mouth of the tunnel and 200 feet beneath the surface, the basalt cap being here over 60 feet in thickness. This last is a very strong statement. Mr. Pierce must have known whether he did or did not dig up this mortar. I know nothing of Mr. Pierce, and it is possible that he may have been fond of practical jokes; but there are surely few men who would carry a joke to the length of deliberately perjuring themselves, and, had Mr. Pierce been capable of such a thing, it is probable that his reputation for untruthfulness would have been notorious. Mr. Pierce, if he is alive, will, I trust, pardon me for treating his credibility as if he were a witness in court. That practical jokes were in vogue in California in early days is certain, and it is unquestionable that Mr. Pierce's affidavit was taken with the express purpose of guarding against the objection that he might not be in earnest.

Mr. Neale's Discoveries.-During the past summer Dr. R. I. Bromley of Sonora called my attention to a mortar in his possession which had been given him as coming from beneath Table mountain. On inquiry I found that the original authority was Mr. J. H. Neale, a resident of Sonora, a mining superintendent by profession, a man of property and of unclouded reputation for veracity-one, in short, who could not afford to perpetrate a deception. Mr. Neale gave me a most intelligent account of his discovery and willingly took an affidavit to the following statement:

Sonora, August 2, 1890.

In $1877 \mathrm{Mr}$. J. H. Neale was superintendent of the Montezuma Tunnel Company, and ran the Montezuma tunnel into the gravel underlying the lava of Table mountain, Tuolumne county. The mouth of the tunnel is near the road which leads in a southerly direction from Rawhide camp, and about three miles from that place. The mouth is approximately 1,200 feet from the present edge of the solid lava cap of the mountain. The course of the tunnel is a little north of east. 
At a distance of between 1,400 and 1,500 feet from the mouth of the tunnei, or of between 200 and 300 feet beyond the edge of the solid lava, Mr. Neale saw several spear-heads, of some dark rock and nearly one foot in length. On exploring further, he himself found a small mortar three or four inches in diameter and of irregular shape. This was discovered within a foot or two of the spear-heads. He then found a large, well-formed pestle, now the property of Dr. R. I. Bromley, and near by a large and very regular mortar, aiso at present the property of Dr. Bromley.

All of these relics were found the same afternoon, and were within a few feet of one another and close to the bed-rock, perhaps within one foot of it.

Mr. Neale declares it utterly impossible that these relics can have reached the position in which they were found excepting at the time the gravel was deposited, and before the lava cap formed. There was not the slightest trace of any disturbance of the mass or of any natural fissure into it by which access could have been obtained, either there or in the neighborhood.

And Mr. J. H. Neale declares upon his oath that the foregoing statement is in every respect true.

JoHn H. Neala.

Subscribed and sworn to before me this second day of August, 1890.

EDWIN A. Roghrs, Notary Public.

The larger mortar and the pestle referred to in this statement are illustrated in the accompanying plate 7 , which is a photo-mechanical reproduction (by the Moss process) of a photograph of the objects, one-third natural size. The rock of which the mortar is made is andesite.

It would have been more satisfactory to me individually if I had myself dug out these implements, but I am unable to discover any reason why Mr. Neale's statement is not exactly as good evidence to the rest of the world as my own would be. He was as competent as I to detect any fissure from the surface or any ancient workings, which the miner recognizes instantly and dreads profoundly. Some one máy possibly suggest that Mr. Neale's workmen "planted" the implements, but no one familiar with mining will entertain such a suggestion for a moment. No workman would dream of planting so large a number of implements, even to deceive a visitor, and he could conceal them only in broken ground. The auriferous gravel is hard picking, in large part it requires blasting, and even a very incompetent superintendent could not possibly be deceived in this way.

It has sometimes been objected to the authenticity of the discoveries of implements in the gravels that the finders, with the exception of Dr. H. H. Boyce, were miners and not scientific men. Now, so far as the detection of a fraud is concerned, a good miner regularly employed in superintending the workings would be much more competent than the average geological visitor. The superintendent sees day by day every foot of new ground exposed, and it is his business to become thoroughly acquainted with its character, while he is familiar with every device for "salting" a claim. The geological vis- 
itor finds a mine timbered and smoked. He cannot fully acquaint himself with the ground, and he is usually unfamiliar with tricks. It is therefore an argument in favor of the authenticity of implements that they have been found by miners. In short, there is, in my opinion, no escape from the conclusion that the implements mentioned in Mr. Neale's statement actually occurred near the bottom of the gravels, and that they were deposited where they were found at the same time with the adjoining pebbles and matrix.

Mr. King's Discovery. - Another unpublished discovery has also been made in these gravels which will be in so far more satisfactory to the members of this Society that the discoverer is well known personally to most of them

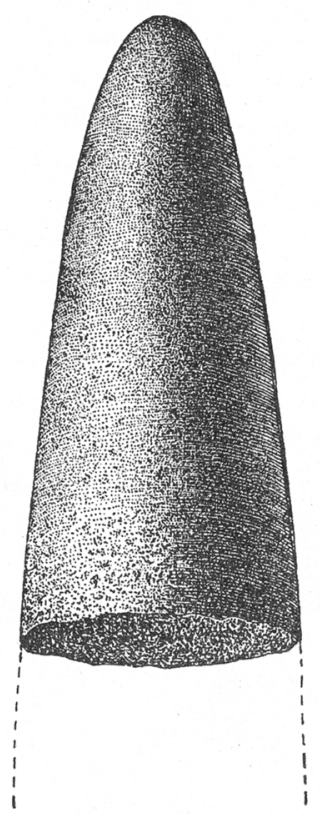

FigURe 1.-Broken Pestle from Auriferous Gravels. One-half natural size.

and by reputation to every geologist. In the spring of $1869 \mathrm{Mr}$. Clarence King visited the portion of the Table mountain which lies a couple of miles southeast of Tuttletown, and therefore near Rawhide camp, to search for fossils in the auriferous gravels. At one point, close to the high bluff of basalt capping, a recent wash had swept away all talus and exposed the underlying compact, hard, auriferous gravel beds, which were beyond all question in place. In examining this exposure for fossils he observed a fractured end of what appeared to be a cvlindrical mass of stone. This mass he 
forced out of its place with considerable difficulty on account of the hardness of the gravel in which it was tightly wedged. It left behind a perfect cast of its shape in the matrix, and proved to be a part of a polished stone implement, no doubt a pestle. It seems to be made of a fine-grained diabase. This implement was presented to the Smithsonian Institution on January 20, 1870. It is shown in the accompanying cut (figure 1), a photo-engraving from a drawing by Mr. W. H. Holmes. Mr. King is perfectly sure that this implement was in place, and that it formed an original part of the gravels in which he found it.* It is difficult to imagine more satisfactory evidence than this of the occurrence of implements in the auriferous, preglacial, sub-basaltic gravels.

The Calaveras Skull.-As is well known, there is also evidence indicating the existence of human remains in the gravel beds, particularly that afforded by the famous Calaveras skull. This strange relic I shall not fully discuss on this occasion, but a few words concerning it will not be out of place. No one has doubted that Mr. Mattison found the skull in the auriferous gravels beneath the lava, 130 feet from the surface, and that he honestly supposed it to be in place; but it has been asserted that it was purposely concealed there by others. Now the chemical analysis of the bone shows that it is a fossil. It.contains only a trace of organic matter, over 62 per cent. of calcium carbonate, and only about 34 per cent. of calcium phosphate. A rhinoceros jaw from the same horizon contained more than two and a half times as much phosphate as carbonate, and was thus much less completely fossilized than the human bone. Truly fossilized human bones are very great rarities, and to suppose that the miners were not only successful in "salting" the mine with human bones, but that they procured truly fossil bones to do it with, requires a painful stretch of the imagination. But, further, when the skull was found a mass of gravel indistinguishable from the surrounding material adhered firmly to it and remained thus attached until, long afterwards, Dr. Jeffries Wyman removed it in Cambridge, Massachusetts. Hence the miners must have found it, if at all, in a formation similar to or identical with the auriferons gravels. The supposed joke would therefore be quite without point.

It has also been suggested that the skull may have fallen from the surface through some crack in the rock at a time sufficiently remote to allow the fossilization and the induration of the surrounding mass to take place. There is no direct evidence in favor of this hypothesis, and it is highly improbable that an open cleft 130 feet deep could be formed by natural causes in a mass of gravel capped by only 40 feet of lava. The fact that part of the tibia of another human being, too small to have owned the skull, was found in the mass adhering to the larger bone makes the suggestion more difficult of

\footnotetext{
- I have submitted this statement of his discovery to Mr. King, who pronounces it correct.
} 
acceptance; and finally the traces of such a cleft would certainly have been detected by Professor Whitney, his three assistants and several personal friends, all of whom carefully examined the locality with the finder of the skull not long after its discovery became known. I find that many good judges are fully persuaded of the authenticity of the Calaveras skull, and Messrs. Clarence King, O. C. Marsh, F. W. Putnam and W. H. Dall have each assured me of his conviction that this bone was found in place in the gravel beneath the lava.* Dr. Alfred R. Wallace, too, who has seen at least some of the auriferous gravels and table mountains, in speaking both of the implements found and the Calaveras skull, stated that these remains "present all the characteristics of genuine discoveries." $\dagger$

Conclusion as to Facts.-The new evidence brought forward in this paper seems to me a considerable contribution to the argument in favor of the authenticity of the skull and amply sufficient of itself to prove that man existed during the Auriferous gravel period in California.

As for the accompanying mammalian remains, $I$ am not aware that their authenticity has ever been questioned, while the Tertiary facies of some of them is freely acknowledged. Since the relics of humanity occur down to the very bottom of the gravels, it seems to me altogether probable that the beasts were contemporaneous with the human beings, for the advent of the last great lava flows and the subsequent glaciation seem the only known events adequate to account for their extinction or expulsion. There is a possibility, however, that the great beasts were all dead before human occupation began, just as to.day implements or human bones might be mingled with the remains of animals already extinct, but still lying at or near the surface. Even on such an hypothesis the remains of Homo sapiens and other animals in the gravels must be referred to the same geological horizon.

Many naturalists like Mr. Wallace would be little surprised at the discovery of paleolithic implements in the Pliocene, for there is considerable evidence that men must have existed in some quarters of the globe thus early. It is the relatively high stage of development indicated by the character of the tools which inclines some students to discredit the discoveries. We seem to be on the horns of a dilemma; either man reached the neolithic stage in California much earlier than in other parts of the globe, or the paleontologists are wrong in their reference of certain of the mammals to the Pliocene fauna. I seem, however, to see a tertium quid worth suggesting, but to which I am not ready to commit myself finally. In order to explain my trial hypothesis I must make a short digression on the age of the glacial phenomena in California.

* This statement is made by permission.

† Nineteenth Century Magazine, Nov. 1887, p. 667. See also "Darwinism," 1889, p. 456. 


\section{Correlation of Lavas and Gravels with Eastern Depositg.}

Recency of Glaciation in California.-It is usual to make the tacit assumption that the Sierra Nevada of California was glaciated contemporaneously with the northeastern portion of North America, and, when it is suggested that the glaciation in the two regions may be independent phenomena, the answer is that some great change in terrestrial or cosmical conditions would seem needful to restore the glacial epoch. So far as the Sierra is concerned, it seems to me that the history of the past twelve months sufficiently disproves this argument. The snowfall last winter in the Sierra was exceptionally large, about 21 times the average precipitation having fallen. Much of this snow remained unmelted through the season, and when I left the mountains, on October 1, there were still thousands of snow banks where in ordinary seasons none remains even far earlier in the season. Many of these banks were also of great depth, say 100 feet, more or less. It is clear, therefore, that were this and succeeding winters to be as wet as the last, the range would show glaciers in great numbers, much as the Alps now do; in short, the glacial period of the Sierra would recur in a moderate way. Now, no one doubts that there was some cause for the unusual snowfall of 1889-'90, but no one has any suspicion what it was. No sensible change in cosmical or terrestrial conditions has occurred, the weather of the world at large was not remarkable, and, excepting as to precipitation, the year was not extraordinary even in California. In short, some very minute change, seemingly local in character, modified very delicately balanced conditions sufficiently to produce results which if repeated would be of great geological importance.

I regard this as proof that the glaciation of the Sierra may possibly have been local, and that it will be reasonable to pronounce it local if good confirmatory evidence to that effect can be adduced.

No one who has examined the glaciated regions of the Sierra can doubt that the great mass of the ice disappeared at a very recent period. The im. mense areas of polished surfaces fully exposed to the severe climate of from say 7,000 to 12,000 feet altitude, the insensible erosion of streams running over glaciated rocks and the freshness of erratic bowlders are sufficient evidence of this. There is also evidence that the glaciation began at no very distant geological date. As Professor Whitney pointed out, glaciation is the last important geological phenomenon and succeeded the great lava flows. There is also much evidence that erosion has been trifling since the commencement of glaciation, excepting under peculiar circumstances. I have discussed the deepening of the cañons of the gold belt in another paper* and need say no more here than that $I$ attribute it to somewhat narrowly restricted local

* This volume, ante, p. 64. 
couditions. East of the range, however, for example at Virginia City, andesites, which there is every reason to suppose preglacial, have scarcely suffered at all from erosion, so that depressions down which water runs at every shower are not yet marked with water-courses, while older rocks, even of Tertiary age and close by, are deeply carved. The rainfall at Virginia City is, to be sure, only about 10 inches, so that rock would erode only say one-third as fast as on the California coast; but even when full allowance is made for this difference, it is clear that these andesites must be much younger than the commencement of glaciation in the northeastern portion of the continent as usually estimated. So, too, the andesites near Clear lake, in California, though beyond a doubt preglacial, have suffered little erosion, and one of the masses, Mount Konocti (or Uncle Sam), has nearly as characteristic a volcanic form as Mount Vesuvius.

Furthermore, it is certain that the great valley of California was formerly a shallow and therefore also a warm gulf. The existence of this sheet of water would unquestionably increase the precipitation on the Sierra and indeed by nearly the whole amount of the evapuration from the gulf. Such a body of water might surely influeuce the climate as much as the imperceptibly small change of conditions which led to last winter's great snowfall, or in other words it may reasonably be supposed to have caused glaciation.

Thus there is evidence that the glaciation of the Sierra began and ended at a late date relatively to the glaciation of the northeastern states, and there is an assignable and even probable local cause for glaciation.

Survival of Pliocene Animals in California.-The reasonable hypothesis of a local glaciation of the Sierra, confined to time limits later than those of what is known as the glacial epoch, may be made to account for the extraordinary association of neolithic implements with Pliocene bones in California. When glaciation began in northeastern America the preëxisting mammalian fauna no doubt died out in part, but it is not probable that all the beasts resigned themselves to death without effort. Many of them must have sought congenial climates in the south and southwest, and no one can doubt that their existence must have continued longest in the more genial portions of the country. The climate of California was then, as now, independent of the great storm-generating divide of the Rocky Mountains, for in the northern hemisphere the prevailing winds are westerly. In California the great expanse of the Pacific ocean must always have affected the climate somewhat as it does now. It thus seems reasonable to suppose that the waning species of vertebrates found a veritable sanitarium west of the Sierra, and that they continued to exist there long after their congeners of the east were extinct.

In short, then, it is not necessary to suppose that man reached the neo. lithic age in California earlier than in Europe, if one supposes that a rem.

XXX-Buli. Grol. Soc. AM., Vol. 2, 1890. 
nant of Pliocene mammals survived on the Pacific coast long after the age which they characterized was past. For such an hypothesis there are certainly analogies. The Australian fauna (and its flora, too) represents a survival, at least, to a certain extent, and the fauna of this hemisphere is of an older type than that of Eurasia. So, too, the tapir of tropical South America nearly resembles the extinct tapir of California. Perhaps he escaped through Mexico when ice appeared on the Sierra. Barrande was driven to the theory of colonies to account for Paleozoic faunal distribution, and the theory is surely as legitimate on the border line between the Tertiary and the recent period as when a mare equable distribution of climate gave less incentive to migration. Dr. C. A. White, too, has done much to show that great caution must be exercised in assuming the simultaneous extinction of species in different regions. Finally, Professor Joseph Leidy, to whom I communicated an abstract of this paper, writes to me from Philadelphia:

"In the Academy here are some bones of the Megalonyx, from a Tennessee cave, retaining portions of articular cartilage and tendinous attachment, and in one instance a nail, apparently indicating the perpetuation of the animal under favorable conditions to a period closely verging on that of the human era."

Conclusion.-As a trial hypothesis, then, the suggestion of a survival of Pliocene animals in California to relatively late Pleistocene times seems worthy of consideration; but it cannot be definitely adopted or rejected until the faunas of the auriferous gravels and allied horizons are more fully investigated. That human remains are really associated with an extinct fauna in these gravels seems to me thoroughly established.

Washington, D. C., December, 1890. 


\section{DISCUSSION.}

Reverend G. Frederick WRIGHT: In the early part of October last while in Sonora to make arrangements for driving to the Yosemite, I was introduced to Mr. C. McTarnahan, assistant county surveyor of Tuolumne county, as a gentleman who could furnish me information concerning Table mountain. On inquiring of him concerning the situation of the Valentine shaft, to which reference is made by Professor Whitney, he was able to tell me the exact locality, though he had never heard of any human relics having been found in it; but he at once said that he had himself recently found a mortar in his father's mine underneath Table mountain. On asking him where the mortar was, he said that it was in the possession of Mrs. M. J. Darwin, of Santa Rosa, who passed through Sonora soon after the discovery, and to whom he gave it.

On returning from the Yosemite, Mr. McTarnahan repeated to me the information more in detail. The discovery was made in October, 1887, in the Empire mine, which was owned in part by his father and in which work is still continued. This mine is on the western side of Table mountain, and was reported upon by E. F. Thomas in the volume published by the state in 1888. This mine lies nearly westward from Shaw's flat, and, from the opening, penetrates the rim underneath Table mountain a distance of 742 feet. Mr. McTarnahan himself found the mortar in the gravel, as work was proceeding, 500 feet from the outside of the rim, which, from the direction of the drift, would make it 200 feet from the apex of the rim under the surface of the basalt. He described the mortar as a granite bowlder about eight inches in diameter, and the hollow four inches in diameter at the surface and three inches deep. There was no possible motive for Mr. Mctarnahan to distort the facts in any way, and the measurenents and other facts, as above given, were stated by him instantaneously in connection with the introduction of the subject, and everything in connection with the account had the appearance of straightforward honesty.

On writing to Mrs. Darwin at Santa Rosa, requesting photographs of the mortar and giving the statement furnished me by Mr. McTarnahan, she sent me a photograph with the measurements on the back side; but she writes that she does not remember to have learned from Mr. McTarnahan that the mortar was found in the tunnel, as that was a circumstance which he did not impress upon her and she does not remember that he mentioned it. 
Altogether, these circumslances seem strongly confirmatory of the genuineness of the object. Mrs. Darwin was a tourist on her way from the Yosemite, and evidently neither she nor Mr. McTarnahan had set any special importance upon the geological position in which the mortar was found. Mr. McTarnahan is a young man, about twenty-five, and had never heard of the discoveries reported by Dr. Snell in the Valentine shaft, and evidently had been totally unimpressed by the archæological discussions with reference to that region; so that the evidence seems to me of a very high order. 